\title{
Amelioration of Acidic Soil to Increase Tef (Eragrostis tef (Zucc) Trotter) Yield on Smallholder Farmer Fields in Ethiopian Highlands
}

\author{
Mekonnen Asrat \\ Department of Plant Sciences, Debre Markos University, Debre Markos, Ethiopia
}

Email address:

mek.asrat@yahoo.com

\section{To cite this article:}

Mekonnen Asrat. Amelioration of Acidic Soil to Increase Tef (Eragrostis tef (Zucc) Trotter) Yield on Smallholder Farmer Fields in Ethiopian Highlands. Journal of Plant Sciences. Vol. 8, No. 1, 2020, pp. 1-11. doi: 10.11648/j.jps.20200801.11

Received: September 6, 2019; Accepted: October 28, 2019; Published: January 8, 2020

\begin{abstract}
Crop productivity of Ethiopian highlands has been declining mainly due to high intensity of acidic soil thus amelioration is vital to improve soil properties and crop yield. Unfortunately, most farmers in Ethiopian highlands in general and in Gozamin district in particular are characterized by economically poor. This study was designed to investigate the effects integrated effects of commercial lime and low cost materials on tef yield. It was conducted under rain fed conditions of 2017 \& 2018 seasons. The factorial combination of three levels lime $(0,1.5$ and $3 \mathrm{t} / \mathrm{ha})$, kitchen ash $(0,1$ and $2 \mathrm{t} / \mathrm{ha})$ and manure $(0,2.5$ and $5 \mathrm{t} / \mathrm{ha}$ ) treatments were laid out in randomized complete block design and replicated three times. Days to maturity were prolonged by highest application rates of lime and manure meanwhile early maturity of the crop recorded at zero application rates. Maximum number of tillers and the longest plant height were obtained at $1.5 \mathrm{t} / \mathrm{ha}$ lime and $5 \mathrm{t} / \mathrm{ha}$ manure applications. Crop yields (grain, straw and biomass) were increased linearly with manure rates meanwhile in quadratic function with application of lime. Maximum grain yield (2.12 t/ha) was obtained from combined $1.5 \mathrm{t}$ lime $+0.5 \mathrm{t}$ kitchen ash $+5 \mathrm{t} / \mathrm{ha}$ manure treatment and followed by $1.97 \mathrm{t} / \mathrm{ha}$ yield through the treatment that received same rate of lime and manure with $1 \mathrm{t}$ kitchen ash. These treatments were increased grain yield by more than one tone over the control. Besides, the economic analysis result confirmed that combined $1.5 \mathrm{t}$ lime, $0.5 \mathrm{t}$ kitchen ash and $5 \mathrm{t} /$ ha manure application gave maximum net profit of 27,629 Birr/ha with acceptable MRR of $18 \%$, thus, this application rate is optimum to increase tef production on small scale farmer fields. However, comprehensive recommendation will be drawn in future by using further findings rather than rely on a single study.
\end{abstract}

Keywords: Acid, Kitchen Ash, Gozamin, Lime, Manure

\section{Introduction}

Ethiopian highlands are endowed with suitable climatic and soil conditions for crop production. However, crop productivity of these regions has been declined gradually despite of its potentials. Most cultivated lands have been degraded due to inappropriate land use, torrential rainfall distribution and intensive cultivation along with low nutrient replenishment for long period of time. Northwestern Ethiopian highland's soils are characterized by highly weathered and low fertile. The degradation of agricultural land poses a serious threat to current and potential food production in the highlands of Ethiopia [1]. On the other hand, as on [2] acidic soils covers about $40 \%$ of Ethiopia and the problem has begun to be visible in the west, southern, south-western and northwestern parts of Ethiopia.

Ethiopia is the origin and center of diversity for tef (Eragrostis tef (Zucc) Trotter). Tef was domesticated in Ethiopia 4000-1000 BC. The crop is an annual, C4grass. Tef is primarily grown to prepare injera (Ethiopian bread), porridge and some local alcoholic drinks. Tef straw is used for animal feed, and mud house constriction. Crop grain has very high level of iron $(80-90 \mathrm{mg} / 100 \mathrm{~g})$ and calcium $(100-110 \mathrm{mg} / 100$ $\mathrm{g}$ ), and about $9 \%$ protein. It is normally eaten with wot, a sauce made of meat and/or pulses; the wot supplements the lysine deficit in tef. The high fiber content of the grain means that it important in preventing diabetes and assisting with blood sugar control [3].

Tef is major crops for Ethiopia, Amhara National Regional State and Gozamin district. The crop is the first cultivated cereal 
crop in terms of area and yield which followed by maize and barley [3]. Tef was covered on 2.6 million hectares of land (about $23 \%$ of the grain crop area) which was more than crop coverage of other major cereals such as maize $(16 \%)$, sorghum (14\%) and wheat (13\%) [4]. In 2011/12 and 2012/13 cropping seasons, it covered on more than 2.7 million hectares of land ( $28.5 \%$ of cereal covered land) in annual and in these seasons it provided over $18 \%$ of the annual grain production (36.3 million quintals) [5]. The same report indicated that in Amhara National Regional State (ANRS) and east Gojjam administrative zone about 1.09 million hectares of land $(33.5 \%$ of cereals) and 240.1 thousands hectares of land $(49.7 \%$ of cereals), respectively occupied by tef in 2012/13 cropping season. In the same season, about 15.28 million quintals tef yield (25.9\% of cereal yield) obtained in Amhara region while 3.622 million quintals (44\% of cereal) in east Gojjam zone. These figures indicated that tef is most important crop in ANRS and east Gojjam zone. However, the crop productivity ranks the lowest as compared to the other cereals grown, little more than one ton per hectare. Though, some efforts have been carried out by Ministry of Agriculture to improve tef productivity through distributing an improved variety, adopting row planting and fertilization technologies the crop productivity has been increased at very low rate. The productivity of tef is very low $\left(785 \mathrm{~kg} \mathrm{ha}^{-1}\right)$ as compared with the productivity of other cereal crop, it attributed by low fertility status of Ethiopian soils [6]. Many factors were suggested to contribute to its lower productivity however wide set of soil fertility problem has great share. In many developing countries, the loss of soil fertility from continual nutrient mining by crop removal without adequate replenishment, combined with imbalanced plant nutrition practices, poses a serious threat to agricultural production. It is already causing yield decreases as large as those caused by other forms of environmental degradation [7]. Similarly, as in [8] tef yields have almost stagnated since 1980, probably due to the occurrence of accelerated soil erosion and lack of appropriate cultural practices on farmers' fields. Moreover, [9] disclosed that tef productivity is strongly affected by soil fertility, acidity and water logging. Besides, acidic and soil infertility limit crop growth and yield as well as soil productivity in highly weathered soils of humid and sub-humid regions of the world due to deficiency of essential nutrient elements [10].

Most Ethiopian highlands soils are rich in iron and aluminum oxides and upon acidification easily release large amounts of aluminum which reaches to toxic for root growth $[11,12]$. Phosphorus is the most limiting nutrients for food production in acidic soils of sub-humid and humid tropical highlands of Ethiopia [13]. Highland's soils are intensively weathered thus higher in sesquioxide ( $\mathrm{Al}$ and $\mathrm{Fe}$ oxides) and fixed $\mathrm{P}$ sources required high amount therefore huge application of mineral $\mathrm{P}$ fertilizers has a significant influence on crop yield. Phosphorus deficiency is a major constraint to crop production on tropical acid soils [14]. Currently, about $41 \%$ of potential arable land of Ethiopia is acidic [2]. Thus, the problem of soil acidity is a critical issue requiring urgent attention in most highlands of Ethiopia due to its impact on crop production and productivity [15]. In Ethiopian highlands, the prevalence of acidity problem is becoming the major yield limiting factor for crop production. Similarly, the potential of most cultivated lands of Amhara National Regional State is affected by soil acidity. The survey conducted in northwestern Ethiopian highlands indicates that $16.2 \%$ of cultivated lands of Amhara National Regional State are categorized under strongly acidic, whereas $28.3 \%$ of the cultivated lands are moderately acidic [16]. Similarly, the potential of most cultivated lands soil of Gozamin district is highly affected by acidity and fertility depletion problem.

The productivity of crop on acid soils is improved through increasing the $\mathrm{pH}$ of soil [17]. Application of soil amendments such as lime is important to correct soil acidity problem and improve crop yield $[18,19]$. The positive effects of liming usually occur through amelioration of $\mathrm{Al}$ and sometimes $\mathrm{Mn}$ toxicity and/or alleviation of $\mathrm{Ca}$ deficiency (Haynes and Naidu, 1998). Liming material with a relative neutralizing value of less than $100 \%$ requires a heavier application than $\mathrm{CaCO}_{3}$ to neutralize an equivalent amount of soil acidity. The neutralizing value relative to calcium carbonate depends on their composition and purity [20]. On this virtue, Amhara Regional State's Bureau of Agriculture has been tried to demonstrate the effect of lime application on crop yield to some area farmers and few farmers have already started using lime to ameliorate soil acidity. Dejen liming material is readily available for the study area.

Several conducted studies indicated that wood ash application ameliorate soil acidity problem [21, 22]. Wood ash consists of significant amount of $\mathrm{P}, \mathrm{K}, \mathrm{Mg}$ and $\mathrm{Ca}$ therefore it supply nutrients and displace soil's $\mathrm{H}^{+}$and $\mathrm{Al}^{3+}$ ions. Besides, wood ash has liming effect and alleviates P deficiencies [21, 22]. As in [23, 24] application of wood ash is effective to improve soil properties and crop yield. On the other hand, application organic fertilizers improve the physiochemical properties of acidic soils and increase crop yield [18]. Manure supplies essential plant nutrients such as $\mathrm{N}, \mathrm{C}$ a, $\mathrm{P}, \mathrm{Mg}, \mathrm{K}$ and chelating soluble $\mathrm{Al}$ and forms insoluble hydroxy-Al compounds and reduce $\mathrm{Al}$ concentration but increase available $\mathrm{P}[25,26]$. An equivalent yield of sorghum was achieved with about $20 \mathrm{t} / \mathrm{ha}$ of compost compared sorghum in acid soil treated with $\mathrm{CaCO}_{3}$ applied at a rate of 0.6-1.7 t/ha [27]. However, as in [28] integrated use of lime and organic fertilizer has higher significant effect on improving the properties of acid soils.

Crop production of small scale farmers is characterized by low returns and poor sustainability. In Ethiopian highlands, the most dominant crop producers are small-scale farmers which depend on subsistent farming that produced under low input management condition [29]. As per [30] report understanding the economic problem of resource poor farmers, developing appropriate nutrient management using low cost technologies is crucial, therefore promoting low cost and risk soil reclamation technologies is vital for these areas. Most farmers of the study area are resource poor and they have a little chance to ameliorate their cultivated field through Dejen liming material due to its unaffordable cost and very hard for 
these farmers. Similarly, [31] study revealed that the practice of liming acid soils is not common in Sub-Saharan Africa (SSA), perhaps because of limited knowledge on lime effectiveness, availability and high hauling costs of liming materials. The amendment of acid soils, most recommended rates of lime are high, which cannot afford to purchase for resource poor farmers [32], therefore integrating management considered the substitute cost and profit of liming material such as wood ash and manure over conventional lime is crucial to improve the livelihood of small-scale farmers. However, meager information is available on optimum application rate for tef production in Ethiopia in general and in study area in particular. Therefore, this study was designed to address the following specific objectives:

(1) To evaluate the effects of lime, kitchen ash and manure on growth and yield of tef

(2) To identify the optimum rate and most profitable management to increase tef production in Gozamin district

\section{Materials and Methodologies}

\subsection{Description of the Study Area}

The experiment was conducted at Yebokla kebele, Gozamin district of Amhara National Regional State (ANRS). The site is located at $311 \mathrm{~km}$ northwest of Addis Ababa. The site lies geographically at $10^{\circ} 26^{\prime} 0.67^{\prime \prime} \mathrm{N}$ and $37^{\circ} 53^{\prime} 42^{\prime \prime} \mathrm{E}$ at 2580 masl altitude. The area has received mean annual rainfall of 1344 $\mathrm{mm}$ and $16.4^{\circ} \mathrm{C}$. Its rainfall characterized by uni-modal pattern which starts in the middle of June and extends to the middle of October, meanwhile peak rainfall received from mid of July to end of August. As per [33] rating of the agro-climatic conditions of site it categorized under highly suitable for tef production. This experiment was conducted under rain fed conditions of 2017 \& 2018 seasons. The distribution of soil types in ANRS is Luvisols, Cambisols, Leptosols, Nitisols, Vertisols, Acrisols and Regosols, respectively [34] thus these soils are dominantly acidic in nature.

\subsection{Experimental Materials}

The test crop was Quncho (Dz-Cr-387 (RIL-355) tef variety which released in 2006 by DzARC/EIAR from two parent materials (DZ-01-974) and Magna (DZ-01-196). The liming material was Dejen calcite lime with moisture content of $1.056 \%$, purity of $91 \%$, fineness factor of $52 \%$ and relative neutralizing value of $47 \%$ [35]. Kitchen Ash that collected from local dwellers was a mixture of tree species, crop residues (crop stalk and cobs) and cattle dung and sieved through $2 \mathrm{~mm}$ sieve size. According to [36] report indicated that calcium carbonate equivalent (CCE) of wood ash was ranged between 13.2 and $92.4 \%$ (averagely 55\%).

\subsection{Sampling and Analysis of Experimental Soil and Farmyard Manure}

Ten soil samples were collected randomly in two-way diagonal fashionat root depth $(0-15 \mathrm{~cm})$ before planting the crop then made in two composite samples for determination of selected physicochemical properties of the soil at Bahir Dar and Debre Markos Soil Testing Laboratories. The soil samples were air dried, grinded and sieved size through a $2 \mathrm{~mm}$ pore size for the analysis of $\mathrm{pH}$, available $\mathrm{P}$ where as, for the determination of total nitrogen and organic carbon the soil was made to pass through $0.5 \mathrm{~mm}$ pore size sieve. Soil $\mathrm{pH}$ determined in a ratio of 1.2.5 soil and water solution while its texture measured with hydrometer method. Total nitrogen estimated by Kjeldhal procedure [37] and organic carbon through wet digestion method [38]. Available phosphorous extracted as per [39] procedure and then the solution measured by spectrophotometer [40]. Exchangeable bases (Ca, Mg, K and $\mathrm{Na}$ ) were extracted with $1 \mathrm{M}$ ammonium acetate $\left(\mathrm{NH}_{4} \mathrm{OAc}\right)$ solution and then $\mathrm{Ca}$ and $\mathrm{Mg}$ determined by atomic absorption spectrophotometer (AAS) while exchangeable $\mathrm{K}$ and $\mathrm{Na}$ measured using flame photometer [41]. Exchangeable acidity estimated by saturating the soil samples with $1 \mathrm{M} \mathrm{KCl}$ solution but titrated with $0.02 \mathrm{M} \mathrm{NaOH}$ [42] while exchangeable $\mathrm{Al}$ extracted from the same solution of $1 \mathrm{M} \mathrm{KCl}$ but titrated with standard solution of $0.02 \mathrm{M} \mathrm{HCl}$.

Farmyard manure was collected from ranches and decomposed under shade for one and half month to minimize the loss of nitrogen. Two composite farmyard manure samples were collected for the determination its moisture content, $\mathrm{pH}$, electrical conductivity, total $\mathrm{N}$, organic carbon, available $\mathrm{P}$, exchangeable $\mathrm{Ca}$ and $\mathrm{Mg}$. Manure moisture content was determined by oven-drying the samples at $105^{\circ} \mathrm{C}$ for 24 hours. The pre-determined rate of manure was adjusted according the procedure of [43] moisture correction factor.

The $\mathrm{pH}$ of farmyard manure was determined in $\mathrm{KCl}$ solution and water with a ratio of 1.2.5 soil and water solution. Its electrical conductivity (ECe) was measured by conductivity meter after the farmyard sample was saturated with distilled water and filtered by suction [31]. Its total $\mathrm{N}$ and organic carbon were estimated as per [37, 38] method, respectively. Available phosphorous was determined as per [39] procedure. Besides, exchangeable $\mathrm{Ca}$ and $\mathrm{Mg}$ of the manure were extracted with $1 \mathrm{M}$-ammonium acetate at $\mathrm{pH} 7$ and measured with atomic absorption spectrophotometer [41].

\subsection{Experimental Design and Procedure}

The factorial combinations of three levels of lime $(0,1.5$ and $\left.3 \mathrm{tha}^{-1}\right)$, kitchen ash $\left(0,1\right.$ and $\left.2 \mathrm{tha}^{-1}\right)$ and manure $(0,2.5$ and $\left.5 \mathrm{tha}^{-1}\right)$ treatments replicated three times and laid out in randomized complete block design. The experimental field was tilled four times by oxen-drawn Maresha and then followed by manual fine seed bed preparation. A gross plot size was $2 \mathrm{~m}$ x $1.5 \mathrm{~m}\left(3 \mathrm{~m}^{2}\right)$. The pre-determined rates of lime and kitchen ash were uniformly spread and thoroughly mixed into the soil before one and half month of crop sowing while the pre-determined rate of manure was broadcasted uniformly to the plot before 15 days of the crop sowing.

The net plot area was determined by excluding the two outermost rows from both sides of plot and $0.25 \mathrm{~m}$ row length at both ends as border; therefore the net area was $1.4 \mathrm{~m}^{2}$. The space between adjacent plots and blocks were kept at $0.5 \mathrm{~m}$ 
and $1 \mathrm{~m}$ apart, respectively. Tef was planted in row with inter-row space of $20 \mathrm{~cm}$ in July at $10 \mathrm{~kg} \mathrm{ha}^{-1}$ rate. Nitrogen fertilizer uniformly applied as per crop package of Amhara Region ( $\left.46 \mathrm{~kg} \mathrm{~N} \mathrm{ha}^{-1}\right), 25 \%$ of the rate $(11.5 \mathrm{~kg} \mathrm{~N} / \mathrm{ha})$ applied at planting while $75 \%$ of the rate $(34.5 \mathrm{~kg} \mathrm{~N} / \mathrm{ha})$ was applied at stem elongation stage of the crop. Similarly, $46 \mathrm{~kg} \mathrm{P}_{2} \mathrm{O}_{5} \mathrm{ha}^{-1}$ phosphorus fertilizer as of TSP was applied at crop sowing. All cultural practices that adopted for tef production were properly implemented during the experimental season. Crop growth and yield indicator parameters data were collected from the net plot area.

\subsection{Data Collection and Analysis}

The crop phenological stages (days to 50\%germinate and heading and days to $90 \%$ maturity) were recorded when of the crop reaches to the respective stage. Crop growth parameters (number of tillers per plant and plant height) were measured from ten randomly selected plants from the middle row of net plot area. Number of tillers per plant counted at late tillering stage of the crop but plant height was measured when the crop reached at $90 \%$ physiological maturity. Crop yield parameters such as grain, straw, biomass yield and harvest index were measured after crop harvested and thrashed from net area. Crop grain yield was measured through adjusting its moisture content at $12.5 \%$. Biomass yield was measured by weighing the sun dried total above ground biomass yield. Harvest index was equated with the ratio of the grain yield to the total biomass yield expressed in a percentage.

The collected data were subjected to analysis of variance by following [44] procedure then analyzed using. General Linear Model (GLM) procedure of Statistical Analysis System SAS software version 9.1 [45]. Significant difference among treatment means was separated using the Least Significant Difference (LSD) at 5\% level.

The economic analysis was performed to identify the economical profitable application rate of lime, manure and kitchen ash for tef production for the study area. Variable cost incorporate costs of input, labor, packaging and transporting and experimental output (grain and straw yield) were estimated according to local market (Yebokla town) price. The cost of each $\mathrm{kg}$ of lime during the application seasons was 2.50birr. While the costs of manure and kitchen ash were estimated interns of its $\mathrm{N}$ fertilizer and lime neutralizing value, thus it valued 0.70 and $1.50 \mathrm{birr} \mathrm{kg}^{-1}$, respectively. The overall cost of labor for crop harvesting, trashing, and winnowing was 250 Birr $100 \mathrm{~kg}^{-1}$ while cost of packaging and transporting was estimated 20 Birr $100 \mathrm{~kg}^{-1}$ seed yield. On the other hand, the experimental output, grain and straw yields were valued 21 and $0.2 \mathrm{Birr} \mathrm{kg}^{-1}$, respectively during harvesting seasons. Then the total viable cost, gross field benefit, net benefit and marginal rate of return were computed according to CIMMYIT partial budget analysis method [46]. Experimental treatments were arranged in increasing order of total variable costthen the dominance analysis performed to exclude dominated treatments from the marginal rate of return analysis in order to recommend economically profitable treatment. Non- dominated treatment with marginal rate of return (MRR) greater or equal to $50 \%$ with the highest net benefit is said to be economically profitable (CIMMYT, 1988).

\section{Results and Discussions}

\subsection{Selected Physicochemical Properties of the Experimental Soil and Manure}

The laboratory analysis results of the pre-planting collected soil sample indicated that the soil was clay in texture and strongly acidic in reaction (Table 1). According to [33] soil $\mathrm{pH}$ rating, the soil is categorized under moderately suitable for tef cultivation. It has high exchangeable $\mathrm{Al}$ but lower in exchangeable base $\left(\mathrm{Ca}, \mathrm{Mg}, \mathrm{K}\right.$ and $\mathrm{Na}$ ). However, $\mathrm{Al}^{+3}$ can be toxic in concentrations as low as 0.04 to $0.08 \mathrm{~mol} \mathrm{~m}^{-3}$ ( 1 to 2 $\mathrm{ppm})$, however, there is great variation of tolerance from one species to another and within particular species [47]. According to [48] rating the soil was low $(0.11 \%)$ in total $\mathrm{N}$ but very low in organic carbon $(1.35 \%)$ and available phosphorus (0.6 ppm) (Table 1). As per [33] land suitability categorization, the soil was marginal suitable for tef production with its available $\mathrm{P}$ and total $\mathrm{N}$ content, thus it required an amendment. The moisture content of farmyard manure was 0.33 while slightly alkaline in reaction with its $\mathrm{pH}$ and non-saline with its electrical conductivity. The manure has very high organic carbon, -exchangeable $\mathrm{Ca}$ and $\mathrm{Mg}$ but medium level in total $\mathrm{N}$ and available $\mathrm{P}$ (Table 1).

Table 1. Physicochemical properties of the soil and farmyard manure.

\begin{tabular}{|c|c|c|c|c|c|}
\hline Parameter & Unit & Soil & Rating & Manure & Rating \\
\hline $\mathrm{pH}\left(\mathrm{H}_{2} \mathrm{O}\right)$ & & 5.1 & Strong acid & 7.76 & Slig. alkaline. \\
\hline $\mathrm{pH}(\mathrm{KCl})$ & & 4.67 & & 7.47 & Slig. Alkaline \\
\hline $\mathrm{EC}$ & $\mathrm{dS} / \mathrm{cm}$ & 0.049 & Non-saline & 0.39 & Non-saline \\
\hline Organic C & $\%$ & 1.35 & Low & 16 & Very high \\
\hline Avail. P & ppm & 0.6 & Very low & 12 & Medium \\
\hline Exch. acid & $\mathrm{Meq} / 100 \mathrm{~g}$ & 1.81 & & - & - \\
\hline Exch. K & $\mathrm{Meq} / 100 \mathrm{~g}$ & 0.28 & Low & - & - \\
\hline Exch. Mg & $\mathrm{Meq} / 100 \mathrm{~g}$ & 0.97 & Low & 21 & Very high \\
\hline Exch. Ca & $\mathrm{Meq} / 100 \mathrm{~g}$ & 3 & Low & 34 & Very high \\
\hline Exch. Na & $\mathrm{Meq} / 100 \mathrm{~g}$ & 0.01 & Very low & - & - \\
\hline CEC & $\mathrm{Meq} / 100 \mathrm{~g}$ & 19 & Moderate & - & - \\
\hline ECEC & $\mathrm{Meq} / 100 \mathrm{~g}$ & 6.07 & & - & - \\
\hline
\end{tabular}




\begin{tabular}{|c|c|c|c|c|c|}
\hline Parameter & Unit & Soil & Rating & Manure & Rating \\
\hline Acid satu. & $\%$ & 29.82 & & - & - \\
\hline Clay & $\%$ & 44 & & - & - \\
\hline Sand & $\%$ & 27 & & - & - \\
\hline Silt & $\%$ & 29 & & - & - \\
\hline Text. class & & Clay & & - & - \\
\hline
\end{tabular}

\subsection{Phenological Stages of the Tef}

\subsubsection{Days to 50\% Emergence}

According to analysis result, days to the emergence were insignificant $(p>0.05)$ to the treatment effects. However, the crop emerged with in a range of 4 and 7 days after crop planting.

\subsubsection{Days to 50\% Heading}

Days to $50 \%$ heading was highly significantly $(p<0.01)$ affected by individual effect of manure while significantly ( $p$ $<0.05$ ) influenced by main effect of lime and its interaction with manure. Days to heading prolonged with application of lime and manure, therefore early heading recorded atzero rates of lime and manure but delayed heading observed with maximum application rate (Table 2).

Table 2. Days to heading affected by main effects of lime and manure.

\begin{tabular}{llll}
\hline $\begin{array}{l}\text { Lime rate } \\
\text { (t/ha) }\end{array}$ & Daysto heading & $\begin{array}{l}\text { Manure rate } \\
\text { (t/ha) }\end{array}$ & $\begin{array}{l}\text { Days to } \\
\text { heading }\end{array}$ \\
\hline 0 & $68.44^{\mathrm{B}}$ & 0 & $67.96^{\mathrm{b}}$ \\
1.5 & $69.04^{\mathrm{AB}}$ & 2.5 & $68.38^{\mathrm{b}}$ \\
3 & $69.19^{\mathrm{A}}$ & 5 & $70.3^{\mathrm{a}}$ \\
Least Critical Range $(0.05)$ & 0.59 & \\
\hline
\end{tabular}

+Means with the same upper and lower case superscripted letter within a column are insignificant at $\mathrm{p}<0.05$ for main effect of lime and manure, respectively

On the other hand, the longest days of crop heading was recorded on combined $5 \mathrm{t}$ manure and $1.5 \mathrm{t} /$ ha lime application, however statistical parity observed between the treatments that received $5 \mathrm{t} /$ ha manure. Early heading of the crop was observed at control treatment (Table 3). Thus, lime and manure application improve soil properties as a result enhance root growth for uptake of nutrients and water, thus flowered and matured on normal period of time. However, on the plots received zero level liming materials, the presence of high aluminum ions in the soils suppressed root development of the crop as a result root growth and development suppressed, thus crop showed early flowering and maturity by the physiological stress. In line with this, early heading bread wheat observed at zero rates of lime and manure while prolonged days at high rates of lime and manure [35].

Table 3. Days to heading of tef heading as affected due to interaction of lime and manure.

\begin{tabular}{llll}
\hline $\begin{array}{l}\text { Lime rate } \\
\text { (t/ha) }\end{array}$ & \multicolumn{3}{l}{ Manure (t/ha) } \\
\cline { 2 - 4 } & $\mathbf{0}$ & $\mathbf{2 . 5}$ & $\mathbf{5}$ \\
\hline 0 & $66.78^{\mathrm{c}}$ & $68.67^{\mathrm{b}}$ & $69.89^{\mathrm{a}}$ \\
1.5 & $68.33^{\mathrm{b}}$ & $68.13^{\mathrm{b}}$ & $70.56^{\mathrm{a}}$ \\
3 & $68.78^{\mathrm{b}}$ & $68.33^{\mathrm{b}}$ & $70.44^{\mathrm{a}}$ \\
Least Critical Range $(0.05)$ & 1.03 & \\
\hline
\end{tabular}

+ Means with the same letter are insignificant at $\mathrm{p}<0.05$

\subsubsection{Days to 90\% Maturity}

Days to maturity was highly significantly $(\mathrm{p}<0.01)$ affected by individual effects of lime and manure. Early matured crop observed at low application rates of lime and manure but the days to maturity of the crop prolonged with the application rates of lime and manure (Table 4). Similarly, [35] report disclosed that bread wheat maturity date prolonged at highest rate of lime and manure while early maturity crop recorded at zero rates.

Table 4. Days to maturity as influenced by main effects of lime and manure.

\begin{tabular}{llll}
\hline $\begin{array}{l}\text { Lime rate } \\
\text { (t/ha) }\end{array}$ & $\begin{array}{l}\text { Days to } \\
\text { maturity }\end{array}$ & $\begin{array}{l}\text { Manure rate } \\
\text { (t/ha) }\end{array}$ & $\begin{array}{l}\text { Days to } \\
\text { maturity }\end{array}$ \\
\hline 0 & $142.63^{\mathrm{B}}$ & 0 & $142.26^{\mathrm{c}}$ \\
1.5 & $143.65^{\mathrm{A}}$ & 2.5 & $143.15^{\mathrm{b}}$ \\
3 & $144.15^{\mathrm{A}}$ & 5 & $145^{\mathrm{a}}$ \\
\hline
\end{tabular}

+Means with the same upper and lower case superscripted letter within a column are insignificant at $\mathrm{p}<0.05$ for main effect of lime and manure, respectively

\subsection{Plant Growth Parameters}

\subsubsection{Number of Tillers Per Plant}

Number of tillers per plant was highly significantly $(p<0.01)$ influenced by main effects of lime and manure. Maximum number of tillers were recorded at $1.5 \mathrm{t} /$ ha lime and $5 \mathrm{t} / \mathrm{ha}$ manure applications while minimum number of tillers at lower rate of lime and manure (Table 5). Lime application increased the number of tillers with logarithmic function $(y=1.57 \ln (x)$ +10.82 at $\left.\mathrm{R}^{2}=71.4 \%\right)$ but linearly $\left(\mathrm{y}=2.24 \mathrm{x}+7.26\right.$ at $\mathrm{R}^{2}=$ $96 \%$ ) with application of manure. According to [49] report manure is a great source of $\mathrm{N}$ nutrient, application of farmyard manure increase soil $\mathrm{N}$ by $20 \%$, as a result initiate the growth of more tillers. Moreover, as per [50] report disclosed that the number of tillers per plant increased as by increasing level of nitrogen. Besides, application of manure has more effect in reducing the exchangeable acidity and exchangeable $\mathrm{Al}$ of soils [51].

Table 5. Number of tillers affected by individual effects of lime and manure.

\begin{tabular}{llll}
\hline Lime (t/ha) & $\begin{array}{l}\text { Number of } \\
\text { tillers/plant }\end{array}$ & Manure (t/ha) & $\begin{array}{l}\text { Number of } \\
\text { tillers/plant }\end{array}$ \\
\hline 0 & $10.59^{\mathrm{B}}$ & 0 & $9.78^{\mathrm{c}}$ \\
1.5 & $12.54^{\mathrm{A}}$ & 2.5 & $11.19^{\mathrm{b}}$ \\
3 & $12.15^{\mathrm{A}}$ & 5 & $14.26^{\mathrm{a}}$ \\
\multicolumn{2}{l}{ Least Critical Range $(0.05)$} & 0.97 & \\
\hline
\end{tabular}

+ Means with the same upper and lower case superscripted letter within a column are insignificant at $\mathrm{p}<0.05$ for main effect of lime and manure, respectively

\subsubsection{Plant Height}

Plant height of the crop was highly significantly $(\mathrm{p}<0.01)$ 
influenced by individual effect of manure and by the interaction effect of all factors meanwhile significantly ( $p$ $<0.05$ ) by main effect of lime and its interaction with kitchen ash. Plant height of tef varies depending upon cultivar and growing environments [50]. Plant height was increased by quadratic function $\left(\mathrm{y}=4.11 \mathrm{x}^{2}+17.44 \mathrm{x}+66.41\right.$ at $\left.\mathrm{R}^{2}=1\right)$ with application of lime, but linearly increased $(y=7.46 x+67.16$ at $\mathrm{R}^{2}=99 \%$ ) with application of manure (Figure 1). This result also supported in [52] study also plant height of tef promoted through the application of N. Similarly, plant height of maize increased with application rate of $\mathrm{N}$ [53]. But in contrary, [50] report revealed that nitrogen had no significant effect on plant height of tef.

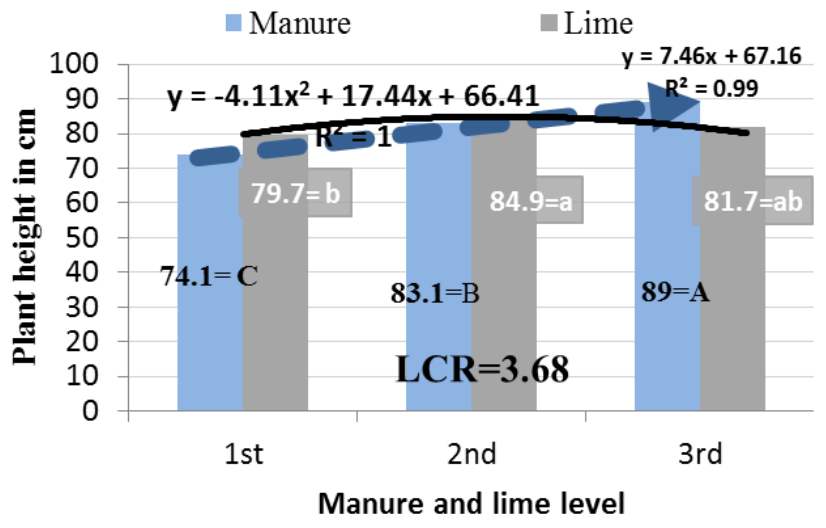

Figure 1. Effect of lime and manure on the height of tef.

On the other hand, the highest plant height $(88 \mathrm{~cm})$ was recorded by combined application of $1.5 \mathrm{t}$ lime and zero kitchen ash but the lowest plant height $(76.9 \mathrm{~cm})$ was observed from the control treatment. However, a statistical parity result was observed between all treatments that received $1.5 \mathrm{t} \mathrm{ha}^{-1}$ lime (Table 6).

Table 6. Plant height affected by interaction of lime and kitchen ash.

\begin{tabular}{llll}
\hline \multirow{2}{*}{$\begin{array}{l}\text { Lime rate } \\
\text { (t/ha) }\end{array}$} & $\mathbf{0}$ & $\mathbf{0 . 5}$ & $\mathbf{1}$ \\
\hline 0 & $76.9^{\mathrm{d}}$ & $78^{\mathrm{cd}}$ & $84.3^{\mathrm{abc}}$ \\
1.5 & $88^{\mathrm{a}}$ & $82.9^{\mathrm{abcd}}$ & $84^{\mathrm{abcd}}$ \\
3 & $80^{\mathrm{bcd}}$ & $86.4^{\mathrm{ab}}$ & $78.8^{\mathrm{cd}}$ \\
Least Critical Range $(0.05)$ & 6.37 & \\
\hline
\end{tabular}

+ Means with the same letters are insignificant at $\mathrm{p}<0.05$

On the other hand, the interaction effect of lime, kitchen ash and manure indicated that the highest plant height $(99 \mathrm{~cm})$ was recorded due to combined application of $1.5 \mathrm{t}$ lime, zero kitchen ash and $5 \mathrm{t} /$ ha manure treatment and followed by 96 $\mathrm{cm}$ with the treatment received $3 \mathrm{t}$ lime, $0.5 \mathrm{t}$ kitchen ash and 5 $\mathrm{t} /$ ha manure and $92 \mathrm{~cm}$ height by combined $1.5 \mathrm{t}$ lime, $1 \mathrm{t}$ kitchen ash and $5 \mathrm{t} / \mathrm{ha}$ manure treatment. However, the shortest plant height of $65-67 \mathrm{~cm}$ was observed from the control and combined zero lime and manure with $0.5 \mathrm{t} / \mathrm{ha}$ kitchen ash treatment. The statistical parity results were recorded among most treatments that received $1 \mathrm{t} /$ ha kitchen ash and $2.5 \mathrm{t} /$ ha manure (Table 7).
Table 7. Plant height as affected by interaction effect of lime, manure and kitchen ash.

\begin{tabular}{lllll}
\hline \multirow{2}{*}{ Lime (t/ha) } & $\begin{array}{l}\text { Manure } \\
\text { (t/ha) }\end{array}$ & \multicolumn{4}{l}{ Kitchen ash (t/ha) } \\
\cline { 2 - 5 } & 0 & $\mathbf{0}$ & $\mathbf{0 . 5}$ & $\mathbf{1}$ \\
\hline \multirow{3}{*}{0} & 2.5 & $77.7^{\text {ij }}$ & $65.7^{\text {j }}$ & $79^{\text {cdefghij }}$ \\
& 5 & $91^{\text {hij }}$ & $83.3^{\text {bcdefgh }}$ & $86.7^{\text {abcdefg }}$ \\
& 0 & $76.7^{\text {defghij }}$ & $85^{\text {abcdefgh }}$ & $87.3^{\text {abcdef }}$ \\
1.5 & 2.5 & $88.5^{\text {abcde }}$ & $87.3^{\text {abcdef }}$ & $72.3^{\text {ghij }}$ \\
& 5 & $99^{\text {a }}$ & $86.3^{\text {abcdefgh }}$ & $97^{\text {abcdef }}$ \\
& 0 & $76.7^{\text {defghij }}$ & $80.7^{\text {cdefghi }}$ & $73.3^{\text {fghij }}$ \\
3 & 2.5 & $80.7^{\text {cdefghi }}$ & $82.7^{\text {bcdefgh }}$ & $81^{\text {cdefghi }}$ \\
& 5 & $82.7^{\text {bcdefgh }}$ & $96^{\text {ab }}$ & $82^{\text {bcdefghi }}$ \\
\multicolumn{2}{l}{ Least critical Range $(5 \%)$} & & & 12.05 \\
\hline
\end{tabular}

+ Means with the same letters are insignificant at $\mathrm{p}<0.05$

\subsection{Crop Yield Parameters}

Crop yield parameters were grain, straw and biomass yields and harvest index. Economical yields of the crop (grain and straw) were significantly influenced by individual effects of lime and manure and interaction effect of lime and manure and interaction of all factors. However, no lodging incidence was occurred during the experimental seasons across all treatments.

\subsubsection{Grain Yield}

Grain yield of the crop was highly significantly $(p<0.01)$ influenced by individual effects of lime and manure meanwhile significantly $(p<0.05)$ affected by interaction effect of lime and manure and interaction of both factors. As per [6] report the national yield of tef is very low which is partly attributed to low soil fertility conditions. Crop grain yield is the most important parameters to determine the effects of treatment. Rates of manure were linearly (grain yield = 287.7 manure +928.3 at $\mathrm{R}^{2}=98 \%$ ) increased grain yield of the crop meanwhile application of lime increased the yield in quadratic function (grain yield $=347.2 \mathrm{x}^{2}+1455 \mathrm{x}+215.7$ at $\mathrm{R}^{2}=1$ ) (Figure 2). In line with this, on [54] study tef yield significantly increased by incorporating biochar and lime, maximum yield obtained from $12 \mathrm{t} \mathrm{ha}^{-1}$ biochar threatened plots as compared with $2 \mathrm{tha}^{-1}$ lime treated ones.

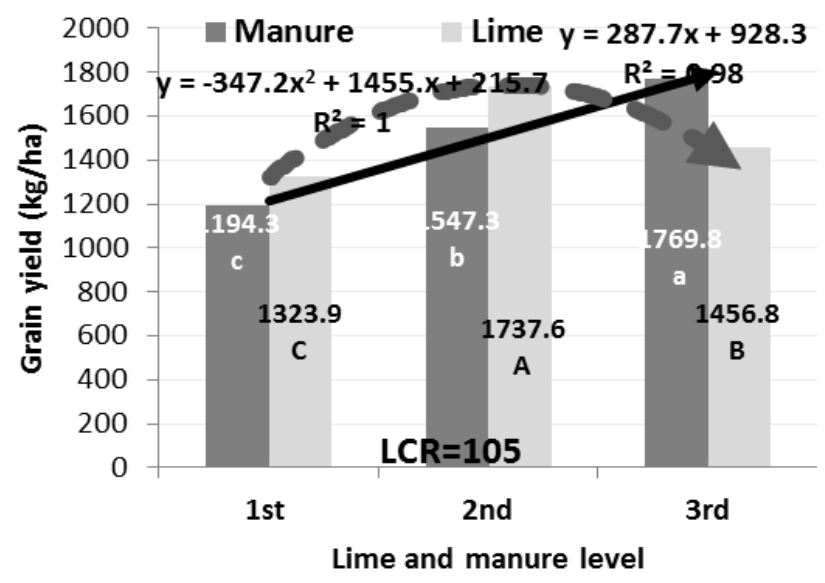

Figure 2. Individual effects of lime and manure on grain yield of tef.

On the other hand, maximum grain yield (2.01t/ha) was 
recorded due to combined application of $1.5 \mathrm{t}$ lime and $5 \mathrm{t} / \mathrm{ha}$ manure but the lowest yield $(0.97 \mathrm{t} / \mathrm{ha})$ was obtained from the control treatment. Statistically, the parity results were recorded among the treatments that received 1.5-3 $\mathrm{t}$ lime and 2.5-5 $\mathrm{t} /$ ha manure (Table 8). Combining use of $1.5 \mathrm{t}$ lime and 5 $\mathrm{t}$ manure increased the grain yield of the crop by one ton over the control treatment. Thus, combined application of manure either with lime or wood ash is the best strategy for resource poor farmers to improve the yield of the wheat [51]. Since lime and wood ash provide cations especially $\mathrm{Ca}^{2+}$ and $\mathrm{Mg}^{2+}$ which suppress the toxicity of $\mathrm{Al}$ in soils as a result enhance roots growth [55].

Table 8. Interaction influence of lime and manure on grain yield by $\mathrm{kg} / \mathrm{ha}$.

\begin{tabular}{llll}
\hline \multirow{2}{*}{$\begin{array}{l}\text { Lime rate } \\
(\mathbf{t} / \mathbf{h a})\end{array}$} & $\mathbf{0}$ & $\mathbf{2 . 5}$ & $\mathbf{5}$ \\
\cline { 2 - 4 } 0 & $968.5^{\mathrm{f}}$ & $1438.5^{\mathrm{de}}$ & $1564.8^{\mathrm{cd}}$ \\
1.5 & $1356.7^{\mathrm{e}}$ & $1860.4^{\mathrm{ab}}$ & $2009.3^{\mathrm{a}}$ \\
3 & $1257.4^{\mathrm{e}}$ & $1377.8^{\mathrm{de}}$ & $1735.2^{\text {cd }}$ \\
Least Critical Range $(0.05)$ & 181.9 & \\
\hline
\end{tabular}

+ Means with the same letters are insignificant at $\mathrm{p}<0.05$

Moreover, maximum grain yield of $2.12 \mathrm{t} / \mathrm{ha}$ was obtained due to interaction of $1.5 \mathrm{t}$ lime, $0.5 \mathrm{t}$ kitchen ash and $5 \mathrm{t} / \mathrm{ha}$ manure treatment mean while the lowest grain yield $(0.89 \mathrm{t} / \mathrm{ha})$ was recorded from the control treatment. The statistical parity results were observed from the treatments that received zero lime and manure across all rates of kitchen ash (Table 9). Integrated.5 t lime, $0.5 \mathrm{t}$ kitchen ash and $5 \mathrm{t} / \mathrm{ha}$ manure treatment gave $1.22 \mathrm{t} / \mathrm{ha}$ more grain yield over the control treatment.

Table 9. Grain yield of the crop $(\mathrm{kg} / \mathrm{ha})$ due to interaction of all factors.

\begin{tabular}{|c|c|c|c|c|}
\hline \multirow{2}{*}{ Lime (t/ha) } & \multirow{2}{*}{$\begin{array}{l}\text { Manure } \\
(\mathbf{t} / \mathbf{h a})\end{array}$} & \multicolumn{3}{|c|}{ Kitchen ash (t/ha) } \\
\hline & & $\mathbf{0}$ & 0.5 & 1 \\
\hline \multirow{3}{*}{0} & 0 & $894.4^{g}$ & $877.8^{g}$ & $1133.3^{\mathrm{g}}$ \\
\hline & 2.5 & $1661.1^{\mathrm{bcd}}$ & $1366.7^{\text {cdef }}$ & $1287.8^{\text {def }}$ \\
\hline & 5 & $1444.4^{\text {cdef }}$ & $1705.6^{\mathrm{bc}}$ & $1544.4^{\text {cde }}$ \\
\hline \multirow{3}{*}{1.5} & 0 & $1388.9^{\text {cdef }}$ & $1136.7^{\mathrm{fg}}$ & $1544.4^{\text {cde }}$ \\
\hline & 2.5 & $1616.7^{\text {bcde }}$ & $1922.2^{\mathrm{ab}}$ & $1961.1^{\mathrm{ab}}$ \\
\hline & 5 & $1944.4^{\mathrm{ab}}$ & $2116.7^{\mathrm{a}}$ & $1966.7^{\mathrm{ab}}$ \\
\hline \multirow{3}{*}{3} & 0 & $1377.8^{\text {cdef }}$ & $1138.9^{\mathrm{fg}}$ & $1255.6^{\mathrm{fe}}$ \\
\hline & 2.5 & $1277.8^{\mathrm{ef}}$ & $1366.7^{\text {cdef }}$ & $1488.9^{\text {cdef }}$ \\
\hline & 5 & $1950^{\mathrm{ab}}$ & $1622.2^{\text {bcde }}$ & $1633.3^{\text {bcde }}$ \\
\hline \multicolumn{4}{|c|}{ Least critical Range (5\%) } & 315.7 \\
\hline
\end{tabular}

+ Means with the same letters are insignificant at $\mathrm{p}<0.05$

\subsubsection{Straw Yield}

Straw yield of the crop was highly significantly $(p<0.01)$ affected by individual and interaction effects of lime and manure but significantly $(\mathrm{p}<0.05)$ by interaction effect of all factors. Application of manure linearly $(y=592.5 x+1524)$ increased the straw yield meanwhile application of lime in quadratic function $(y=372.8 \times 2+1531 x+1388)$ (Figure 3$)$. In line with this, on [51] study an application of lime increased shoot biomass yield due to its effectiveness in reducing the exchangeable acidity and exchangeable Al.

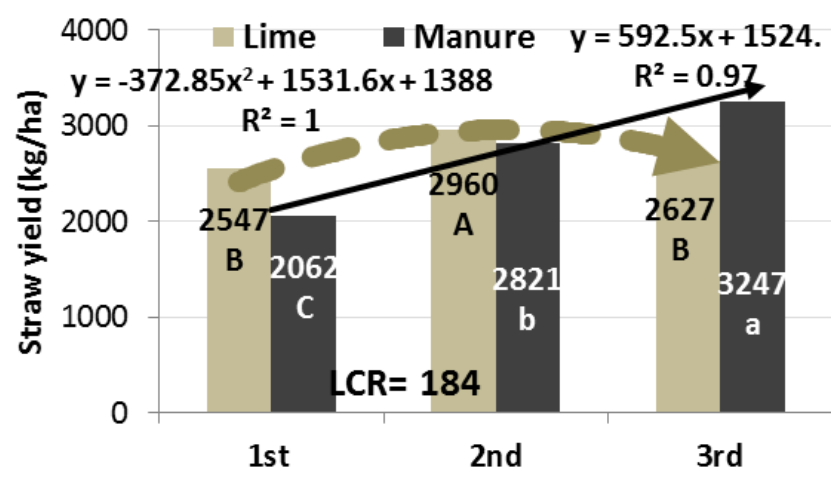

Lime and manure level

Figure 3. Main effects of lime and manure on straw yield.

On the other hand, combined application of 1-5-3 t lime and 5 t/ha manure gave maximum straw yield (3.37 t/ha) meanwhile the lowest straw yield $(1.77 \mathrm{t} / \mathrm{ha})$ was recorded from the control treatment. Statistical parity results were observed from the treatments that revived zero manure (Table 10) it might be due to as a source of $\mathrm{N}$. In contrast to this finding, the application of manure had showed insignificant difference $(\mathrm{P} \leq 0.001)$ on wheat plant height, fresh shoot biomass and dry root biomass as compared to the control treatment [51].

Table 10. Straw yield $(\mathrm{kg} / \mathrm{ha})$ as affected by interaction of lime and manure.

\begin{tabular}{|c|c|c|c|}
\hline \multirow{2}{*}{$\begin{array}{l}\text { Lime rate } \\
(t / h a)\end{array}$} & \multicolumn{3}{|c|}{ Manure (t/ha) } \\
\hline & $\mathbf{0}$ & 2.5 & 5 \\
\hline 0 & $1772.6^{\mathrm{e}}$ & $2866.3^{\mathrm{c}}$ & $3001.5^{\mathrm{bc}}$ \\
\hline 1.5 & $2297^{d}$ & $3250^{\mathrm{ab}}$ & $3364.8^{\mathrm{a}}$ \\
\hline 3 & $2115.2^{\mathrm{d}}$ & $2393^{d}$ & $3373.7^{\mathrm{a}}$ \\
\hline \multicolumn{2}{|c|}{ Least Critical Range ( 0.05$)$} & 319.3 & \\
\hline
\end{tabular}

+ Means with the same letters are insignificant at $\mathrm{p}<0.05$

Besides, maximum straw yield (3.49 t/ha) was obtained through combined use of $1.5 \mathrm{t}$ lime, $0.5 \mathrm{t}$ kitchen ash and $5 \mathrm{t} / \mathrm{ha}$ manure or with combined $3 \mathrm{t}$ lime, $5 \mathrm{t} /$ ha manure and zero rate of kitchen ash treatment. However, the lowest straw yield (1.47 t/ha) was recorded from the control treatment (Table 11). Most treatments that received zero lime were showed statically parity result. Similarly, increasing both lime and wood ash application levels significantly $(\mathrm{P} \leq 0.001)$ increased the plant height, fresh shoot biomass and dry root biomass of wheat [51].

Table 11. Straw yield due to interaction of lime, manure and kitchen ash.

\begin{tabular}{|c|c|c|c|c|}
\hline \multirow{2}{*}{ Lime (t/ha) } & \multirow{2}{*}{$\begin{array}{l}\text { Manure } \\
\text { (t/ha) }\end{array}$} & \multicolumn{3}{|c|}{ Kitchen ash (t/ha) } \\
\hline & & $\mathbf{0}$ & 0.5 & 1 \\
\hline \multirow{3}{*}{0} & 0 & $1466.7^{\mathrm{h}}$ & $1922.2^{\text {gh }}$ & $1928.9^{\text {gh }}$ \\
\hline & 2.5 & $3216.7^{\mathrm{ab}}$ & $3088.9^{\mathrm{abc}}$ & $2293.3^{\mathrm{efg}}$ \\
\hline & 5 & $2950^{\text {abcd }}$ & $3194.4^{\mathrm{abc}}$ & $2860^{\text {abcde }}$ \\
\hline \multirow{3}{*}{1.5} & 0 & $2325.6^{\operatorname{defg}}$ & $1938.9^{\text {gh }}$ & $2626.7^{\text {bcdef }}$ \\
\hline & 2.5 & $2850^{\text {abcde }}$ & $3372.2^{\mathrm{a}}$ & $3394.4^{\mathrm{a}}$ \\
\hline & 5 & $3261.1^{\mathrm{ab}}$ & $3483.3^{\mathrm{a}}$ & $3350^{\mathrm{a}}$ \\
\hline \multirow{3}{*}{3} & 0 & 2250 efg & $1938.9 \mathrm{gh}$ & $2106.7 f g$ \\
\hline & 2.5 & $2053.3 \mathrm{fgh}$ & $2570 \mathrm{cdefg}$ & $2555.6 \mathrm{cdefg}$ \\
\hline & 5 & $3494.4 \mathrm{a}$ & $3356.7 \mathrm{a}$ & $3270 \mathrm{ab}$ \\
\hline \multicolumn{2}{|c|}{ Least critical Range (5\%) } & & & 554.3 \\
\hline
\end{tabular}

+ Means with the same letters are insignificant at $\mathrm{p}<0.05$ 


\subsubsection{Biomass Yield}

The biomass yield of tef was highly significantly $(\mathrm{p}<$ 0.01 ) affected by individual effects of lime and manure and interaction effect of lime and manure and interaction of all factors. Manure rates were increased the biomass yield of the crop in linearly $\left(\mathrm{y}=880.3 \mathrm{x}+2452 . \mathrm{R}^{2}=0.98\right)$ meanwhile application of lime increased biomass in quadratic ways $\left(\mathrm{y}=-720 \mathrm{x} 2+2986 . \mathrm{x}+1604 \mathrm{R}^{2}=1\right)$ (Figure 4). Thus, application of $1.5 \mathrm{t} / \mathrm{ha}$ and $5 \mathrm{t}$ manure gave maximum biomass yield.

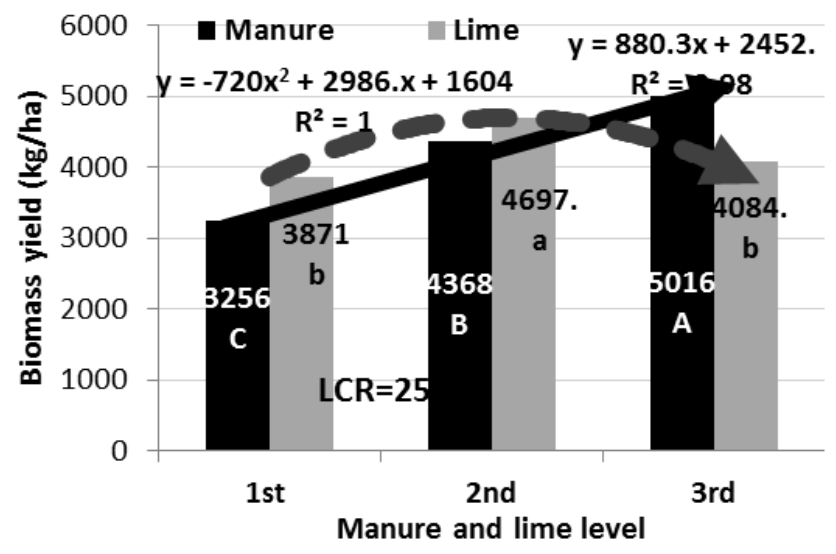

Figure 4. The effects of lime and manure on biomass yield.

On the other hand, the highest biomass yield (5.37 t/ha) was obtained due to combined use of $1.5 \mathrm{t}$ lime and $5 \mathrm{t} /$ ha manure, it had parity statistically with treatments that received $5 \mathrm{t}$ lime $+2.5 \mathrm{t} /$ ha manure and $3 \mathrm{t}$ lime $+5 \mathrm{t} /$ ha manure. The lowest biomass yield of $2.74 \mathrm{t} / \mathrm{ha}$ was recorded from the control treatment (Table 12).

Table 12. Biomass yield due to interaction effect of lime and manure.

\begin{tabular}{|c|c|c|c|}
\hline \multirow{2}{*}{$\begin{array}{l}\text { Lime rate } \\
\text { (t/ha) }\end{array}$} & \multicolumn{3}{|c|}{ Manure (t/ha) } \\
\hline & 0 & 2.5 & 5 \\
\hline 0 & $2741.1^{d}$ & $4304.8^{b}$ & $4566.3^{b}$ \\
\hline 1.5 & $3653.7^{\mathrm{c}}$ & $5110.4^{\mathrm{a}}$ & $5374.1^{\mathrm{a}}$ \\
\hline 3 & $3372.6^{c}$ & $3770.7^{\mathrm{c}}$ & $5108.9^{\mathrm{a}}$ \\
\hline \multicolumn{2}{|c|}{ Least Critical Range $(0.05)$} & 442.8 & \\
\hline
\end{tabular}

+ Means with the same letters are insignificant at $\mathrm{p}<0.05$

Besides, the interaction of $1.5 \mathrm{t}$ lime $+0.5 \mathrm{t}$ kitchen ash + $5 \mathrm{t} /$ ha manure gave maximum biomass yield of $5.6 \mathrm{t} / \mathrm{ha}$ and showed it statistical parity result with treatments that received $1.5 \mathrm{t}$ lime $+1 \mathrm{t}$ kitchen ash $+2.5 \mathrm{t} /$ ha manure and $3 \mathrm{t}$ lime $+0 \mathrm{t}$ kitchen ash $+5 \mathrm{t} /$ ha manure. The lowest biomass yield $(2.36 \mathrm{t} / \mathrm{ha})$ was recorded from the control treatment (Table 13). Most treatments that received combined $1.5 \mathrm{t}$ lime and $5 \mathrm{t} /$ ha manure showed statistical parity response across all rates of kitchen ash. It supported on [51] study also an applications of both lime and wood ash separately significantly $(\mathrm{P} \leq 0.001)$ increased the dry shoot biomass yield and $\mathrm{P}$ uptake as compared to the control treatment.
Table 13. The interaction effect of all factors on biomass yield.

\begin{tabular}{|c|c|c|c|c|}
\hline \multirow{2}{*}{ Lime (t/ha) } & \multirow{2}{*}{$\begin{array}{l}\text { Manure } \\
\text { (t/ha) }\end{array}$} & \multicolumn{3}{|c|}{ Kitchen ash (t/ha) } \\
\hline & & $\mathbf{0}$ & 0.5 & 1 \\
\hline \multirow{3}{*}{0} & 0 & $2361.1^{j}$ & $2800^{\mathrm{ij}}$ & $3062.2^{\text {hij }}$ \\
\hline & 2.5 & $4877.8^{\text {abcde }}$ & $4455.6^{\text {bcdef }}$ & $3501^{\text {fghi }}$ \\
\hline & 5 & $4394.4^{\text {cdef }}$ & $4900^{\text {abcde }}$ & $4404.4^{\text {cdef }}$ \\
\hline \multirow{3}{*}{1.5} & 0 & $3714.4^{\mathrm{fgh}}$ & $3075.6^{\text {hij }}$ & $4171.1^{\text {defg }}$ \\
\hline & 2.5 & $4466.7^{\text {bcdef }}$ & $5294.4^{\mathrm{abc}}$ & $5355.6^{\mathrm{ab}}$ \\
\hline & 5 & $5205.6^{\mathrm{abc}}$ & $5600^{\mathrm{a}}$ & $5316.7^{\mathrm{ab}}$ \\
\hline \multirow{3}{*}{3} & 0 & $3627.8^{\text {fghi }}$ & $3127.8 .8^{\mathrm{hij}}$ & $3362.2^{\text {ghi }}$ \\
\hline & 2.5 & $3331.1^{\text {ghi }}$ & $3936.7^{\mathrm{fgh}}$ & $4044.4^{\mathrm{fg}}$ \\
\hline & 5 & $5444.4^{\mathrm{a}}$ & $4978.9^{\mathrm{abcd}}$ & $4903.3^{\text {abcde }}$ \\
\hline \multicolumn{4}{|c|}{ Least critical Range ( $5 \%)$} & 768.6 \\
\hline
\end{tabular}

+ Means with the same letters are insignificant at $\mathrm{p}<0.05$

\subsubsection{Harvest Index}

Harvest index of the crop highly significantly $(p<0.01)$ affected by individual effect of lime, while significantly $(\mathrm{p}<$ 0.05 ) influenced by kitchen ash. Since wood ash is sources of plant nutrients except $\mathrm{N}$ and used as liming agents [56]. Maximum harvest index recorded from $1.5 \mathrm{t} / \mathrm{ha}$ lime and treatments that that received the lowest and highest rate of kitchen ash (Table 14). Thus, lime and kitchen ash were showed inverse parabolic relation to wards the response of harvest index of tef.

Table 14. Harvest index (\%) affected by main effects of lime and kitchen ash.

\begin{tabular}{llll}
\hline Lime (t/ha) & Harvest index & Kitchen ash (t/ha) & Harvest index \\
\hline 0 & $34.5^{\mathrm{B}}$ & 0 & $36.42^{\mathrm{a}}$ \\
1.5 & $37^{\mathrm{A}}$ & 0.5 & $34.68^{\mathrm{b}}$ \\
3 & $35.98^{\mathrm{B}}$ & 1 & $36.36^{\mathrm{a}}$ \\
Least Critical Range $(0.05)$ & 1.51 & \\
\hline
\end{tabular}

+Means with the same upper and lower case superscripted letter within a column are insignificant at $\mathrm{p}<0.05$ for main effect of lime and kitchen ash, respectively

\subsection{Economic and Correlation Analysis Results}

The economic analysis showed that most treatments were showed dominated result but combined $1.5 \mathrm{t} /$ ha lime, $0.5 \mathrm{t} / \mathrm{ha}$ kitchen ash and $5 \mathrm{t} / \mathrm{ha}$ manure treatment gave maximum net benefit of 27,629 Birr/ha with an acceptable MRR of $18 \%$.

Days to emergence of the crop insignificantly associated to all parameters while days to heading and maturity were highly significantly $(\mathrm{p}<0.01)$ and positively associated all parameters except harvest index. Plant growth indicator parameters (number of tillers and plant height) were correlated highly significantly $(\mathrm{p}<0.01)$ and positively to crop yield parameters. Besides correlation associations among the yield parameters were also highly significant $(\mathrm{p}<0.01)$ and positive except harvest index (Table 15). Harvest index positively but insignificantly associated to grain yield while negatively to straw and biomass yield. In line with this, study tef grain yield was significantly $(\mathrm{p}<0.01)$ and positively correlated with biomass yield of the crop [57]. In contrast to the current finding grain yields of tef significantly $(p<0.01)$ and positively correlated to harvest index of the crop [57]. 
Table 15. Pearson correlation coefficients among crop parameters

\begin{tabular}{llllllll}
\hline & DH & DM & NT & PH & GY & SY & BY \\
\hline DM & $0.54^{* *}$ & & & & & & \\
NT & $0.54^{* *}$ & $0.51^{* *}$ & & & & & \\
PH & $0.43^{* *}$ & $0.52^{* *}$ & $0.56^{* *}$ & & & & \\
GY & $0.48^{* *}$ & $0.43^{* *}$ & $0.54^{* *}$ & $0.40^{*}$ & & & \\
SY & $0.41^{* *}$ & $0.46^{* *}$ & $0.47^{* *}$ & $0.43^{* *}$ & $0.83^{* *}$ & & \\
BY & $0.45^{* *}$ & $0.45^{* *}$ & $0.51^{* *}$ & $0.43^{* *}$ & $0.93^{* *}$ & $0.99^{* *}$ & \\
HI & 0.08 & -0.05 & 0.10 & -0.04 & 0.22 & $-0.35^{* *}$ & -0.15 \\
\hline
\end{tabular}

$+\mathrm{DH}=$ Days to Heading, DM= Days to Maturity, NT= Number of Tillers, $\mathrm{PH}=$ Plant Height, $\mathrm{GY}=$ Grain Yield, $\mathrm{SY}=$ Straw Yield, BY= Biomass Yield, $\mathrm{HI}=$ Harvest Index, ${ }^{*}$ and ${ }^{* *}$, are significant at alpha level of 0.05 and 0.01 , respectively

\section{Conclusion and Recommendation}

Northwestern Ethiopian highlands soils are characterized by acidity. Most farmers of the area are resource poor who have a little chance to ameliorate their lands through commercial lime materials due to the economical constraint. Thus, combining the commercial lime with low cost liming materials is acceptable and profitable to small-scale farmers. The integrated effects of lime, manure and ash on tef yield study was conducted in 2017 and 18 on Gozamin acidic soils.

Early matured crop was observed at low application rate of lime and manure while late matured crop was recorded at higher application rates. Lime applications increased crop growth and yield parameters in quadratic function while the parameters response linearly increased by applications of manure. Combined application of $1.5 \mathrm{t}$ lime $+0.5 \mathrm{t}$ kitchen ash $+5 \mathrm{t} / \mathrm{ha}$ manure increased grain and straw yield of the crop, moreover the economic analysis result confirmed this treatment gave maximum net profit of $27,629 \mathrm{Birr} / \mathrm{ha}$ with acceptable MRR of $18 \%$. Thus, integrated use of $1.5 \mathrm{t} / \mathrm{ha}$ lime, $0.5 \mathrm{t} / \mathrm{ha}$ kitchen ash and $5 \mathrm{t} / \mathrm{ha}$ manure found optimum to increase tef yield on acidic soils of small scale farmers fields of Gozamin district. However, to put forward the comprehensive recommendation further studies on different locations and seasons will be required.

\section{Acknowledgements}

The author extends his special thanks to Debre Markos University for the financial support.

\section{References}

[1] Sonneveld, B. and Keyzer, M.. Land under pressure: Soil conservation concerns and opportunities for Ethiopia. Land Degradation \& Development, 2003. 14: 5-23.

[2] Mesfin A. Nature and Management of Acid Soils in Ethiopia. www.eiar.gov.et/Soil/soils_acid.pdf. 2007.
[3] Winch T. Growing Food A Guide to Food Production. Published by Springer. Dordrecht, The Netherlands. 2006.

[4] CSA (Central Statistical Agency). Agricultural Sample Survey 2007/2008. Report on area and production for major crops, (private peasant holdings, Meher season). Statistical Bulletin, 417. Addis Ababa, Ethiopia. 2008.

[5] CSA (Central Statistical Agency) The Federal Democratic Republic of Ethiopia Central Statistical Agency, Agricultural Sample Survey, volume I, reportonarea and production of major crops (private peasant holdings, 2012/13 meher season), Addis Ababa, Ethiopia. 2013.

[6] Tefera, H., Ayele M., Assefa K. Improved varieties of tef (Eragrostis tef) releases 1970-1995. Research Bulletin No. 2, Debre-Zeit Agricultural Research Centre, Ethiopia. 1995.

[7] FAO (Food and Agriculture Organization). Guide to efficient plant nutrition management, challenges sources of plant nutrients management of plant nutrients environmental issues policies. Land and water development division FAO of the United Nations. Rome, Italy. 1998.

[8] Fufa, H., Tesfa, B., Hailu, T., Kibebew, A., Tiruneh, K., Aberra, D. and Seyfu, K. 2001. Agronomy research in Tef. In: Hailu, T., Getachew, B. and Mark, S. (eds), Narrowing the rift. Tef research and development. Proceedings of the International Workshop on Tef Genetics and Improvement, 16-19 Oct 2000, Debre Zeit, Ethiopia, pp. 167-176.

[9] Wakene, N., \&Yifru, A. Soil Fertility Management of Tef. In K. Assefa, S. Chanyalew, \& Z. Tadele (Eds) (2013). Achievements and Prospects of Tef Improvement; Proceedings of Second International Workshop, November 7-9 2011. Debre-Zeit, Ethiopia. 2013.

[10] Akinrinade, E., Iroh I., Obigbesan G., Hilger T., Romheld, V. and Neumann, G. Response of cowpea varieties to phosphorus supply on an acidic Alumi-haplic-Acrisol from Brazil. Nigerian Journey of Soil Science. 2006. 16: 115-120.

[11] Tekalign M., Haque, I. and Kamara, C. Phosphorus status of some Ethiopian highland Vertisols. In: Jutiz, S. C. Haque, I. McIntire, J. and Stares, J. (eds.), Management of Vertisols in Sub-Saharan Africa. Proceedings of a Conference, ILCA, 232-252, August 31 to September 4, 1987, Addis Ababa, Ethiopia. 1988.

[12] Upjohn, B. Fenton, G. and Conyers, M. Soil acidity and liming. Agfact AC. 19, $3^{\text {rd }}$ edition AGDEX 534, State of New South Wales, Wagga Agricultural Institute, 1-24.

[13] Solomon D., Lehmann, J. Tekalign M., Fritzsche, F. and Zech, W. 2002. Phosphorus forms and dynamics as influenced by land use changes in the sub-humid Ethiopian highlands. Geoderma, 105: 21-48.

[14] Keerthisinghe, F. Zapata, P. Chalk, P. and Hocking, P. Integrated Approach for Improved P Nutrition of Plants in Tropical Acid. Plant nutrition-Food security and sustainability of agro-ecosystems. Kluwer Academic Publishers, the Netherlands. 2001 .

[15] Endalkachew F., Kibebew K., Asmare M., Bobe B., BirruY. and B. Mishra. Effects of Lime, Mineral P, Farmyard Manure and Compost on Selected Chemical Properties of Acid Soils in Lay Gayint District, Northwestern Highlands of Ethiopia. International Journal of Plant \& Soil Science. 19 (2): 2017. 1-16, Article no. IJPSS. 35915, ISSN: 2320-7035. 
[16] IOANRS (Investment Office of Amhara National Regional State). Potential Survey, Identification of Opportunities and Preparations of Projects, Profiles and Feasibility Studies. Part one potential assessment, unpublished soil survey study report by Development Studies Association (DSA) and Shawel Consult International (SCI). 2006.

[17] Whalen, J. Chang, C. Clayton, G. and Care foot J. Cattle manure amendments can increase the $\mathrm{pH}$ of acid soils. Soil Science Society of America Journal, 2000. 64: 962-966.

[18] IFPRI (International Food Policy Research Institute). Fertilizer and Soil Fertility Potential in Ethiopia, Constraints and Opportunities for Enhancing the System. Sustainable solution for ending hanger and poverty Contributed by Gete Z. Getachew A., Dejene A., Shahid, R. Working paper, (http://www.ifpri.org.) 2010. pp1-66.

[19] Abebe Z. and Tolera A. Yield response of faba bean to fertilizer rate, rhizobium inoculation and lime rate at Gedo highland, western Ethiopia. Global Journal of Crop, Soil Science and Plant Breeding. 2014. 2: 134-139.

[20] EIAR (Ethiopian Institute of Agricultural Research). Soil Acidity and Amendments. Merrier, research' in Amharic a monthly newsletter. ISSN 1015-9762, Vol. 9, No. 18. Addis Ababa, Ethiopia. 2009.

[21] Saarsalmi, A., M. Kukkola, M. Moilanen and M. Arola. Long-term effect of ash and $\mathrm{N}$ fertilization on stand growth, tree nutrient status and soil chemistry in a Scots pine stand forest. Ecological Management 2006. 235: 116-128.

[22] Insam, H., Franke-Whittle I. Knapp B, and Plank R. Use of wood ash and anaerobic sludge for grassland fertilization: Effects on plants and microbes. Die Bodenkultur. 2009. 60: $39-51$.

[23] Naylor, L. M. and E. J. Schmid, Agricultural use of wood ash as a fertilizer and liming material. Tappi Journal. 1986. 69: 114-119.

[24] Ohno, T. and M. S. Erich, 1990. Effect of wood ash application on soil $\mathrm{pH}$ and soil test nutrient levels. Agric. Ecosystems Environ. 32: 223-239.

[25] Hati, K. Swarup, A. Singh, D. Misra, A. and Ghos, P. Long-term continuous cropping, fertilization and manure effects on physical properties and organic carbon content of a sandy loam soil. Australian Journal of Soil Research. 2006. 44: 487-495.

[26] Naramabuye, F. Haynes, R. and Modi, A. Cattle manure and grass residues as liming materials, in a semi-subsistence farming system. Agriculture, Ecosystems and Environment, 124: 136-141. doi: 10.1016/j.agee.2007.08.005.

[27] Mgonigaba M. Etude de I "impact des compost a base de biomass Vegetable suriadynamiqu des indicators physico-chimiqueset Microbiologiques de is fertility des soils. Application surtrios soils acides. Tropicaux de Rwanda" Gembloux, Belgiqeue. Faculite Universitaire des Sciences Agronomiques. 2007. 317p.

[28] Opara-Nadi, O. A. Liming and organic matter interaction in two Nigerian Ultisols. Effect on soil $\mathrm{pH}$, organic carbon and early growth of maize (Zea mays. L). Proceedings of the $16^{\text {th }}$ annual conference of Soil Science Society of Nigeria. Minna, Niger state. Nov 27-30th 1988. 177-198 pp.

[29] Bekele, H., J. Worku, T. Feyissa, A. Mulugeta, Y. Mengistu and K. Arfasa, 1998. The Dinsho farming system of Bale highlands.
Chilot (editor). In: Barley based farming systems in the highlands of Ethiopia. Ethiopian Agricultural Research Organization. Addis Ababa, Ethiopia. P. 177.

[30] Dudal, R. Forty years of soil fertility work in sub- Saharan Africa. In: Vanlauwe, B., Diels, J., Sanginga, N. and Merckx, R. $(e d s)$. Integrated plant nutrient management in Sub-Saharan Africa. From concept to practice. CABI Publishing. 2002. 7-21 pp.

[31] Okalebo, J., Gathua K. and Womer P. Laboratory methods of sol and plant analysis: a working manual, $2^{\text {nd }}$ Ed. TSBF-CIAT and SACRED Africa, Nairobi, Kenya. 2002. $128 \mathrm{pp}$.

[32] Gitari, H. Lime and manure application to acid soils and their effects on bio-chemical soil properties and maize performance at Kavutiri- Embu County. MSc Thesis, Kenyatta University, Kenya. 2013.

[33] Mohammed A. Land Suitability Evaluation in the Jelo Catchment, Chercher Highlands, Ethiopia. PhD Dissertation, University of the Free State, Bloemfontein, South Africa. 2003.

[34] Bureau of Agriculture. 1999. Agricultural Master Plan of the Amhara National Regional State Technical report on soil and water management, Bahir Dar, Ethiopia.

[35] Mekonnen A., Heluf G., Markku Y., Bobe B. and Wakene N. Effect of integrated use of lime, manure and mineral $\mathrm{P}$ fertilizer on bread wheat (Triticum aestivum L.) yield, uptake and status of residual soil $\mathrm{P}$ on acidic soils of Gozamin District, north-western Ethiopia. Agriculture, Forestry and Fisheries. 2014. 3 (2): 76-85.

[36] Vance, E. D., 1996. Land application of wood-fired and combination boiler ashes: An overview. Journal of Environmental Quality. 2005. 25: 937-944.

[37] Jackson, M. L.. Soil Chemical Analysis. Prentice-Hall of India, New Delhi. 1967.

[38] Walkley, A. and Black C. An examination of different methods for determining organic carbon content. 1934.

[39] Olsen, S. R., C. V. Cole, Watanabe F. S. and Dean L. A. Estimation of Available Phosphorus in Soils by Extraction with Sodium Bicarbonate. U. S. Department of Agriculture Circular No. 939. Banderis, A., Barter D. and Anderson K. 1954.

[40] Murphy, J. and J. P. Riley. A. modified single solution method for the determination of phosphate in natural waters. Anal. Chim. Acta 1962. 27: 31-36.

[41] Sahlemedhin S. and Taye B. Procedure for soil and plant analysis. National Soil Research Centre, Ethiopian Agricultural Research Organization, Addis Ababa, Ethiopia.

[42] Rowell, D. Soil science: Methods and applications. Addison Wesley Longman Limited England. 1994,350pp.

[43] FAO (Food and Agriculture Organization). Methods of Analysis for Soils of Arid and Semi-arid Regions. Edited by Issam I. and Antoine H. Rome, Italy. 2007.

[44] Gomez, K. A. and Gomez, A. A. Statistical Procedures for Agricultural Research. $2^{\text {nd }}$ edition, John Wiley and Sons Inc., New York. 1984. 328- 332 pp.

[45] SAS (Statistical Analysis System). SAS/STAT User's Guide, Version 9.1.3. SAS institute Inc., Cary, NC. 2004. 
[46] CIMMYT (International Center for Maize and Wheat Development). Agronomic data to farmer recommendations: an economic work book, 1988.

[47] Dent, D. Acid Sulphate Soils: A Baseline for Research and Development, International Land Reclamation Institute, Wageningen, Netherlands. 1986.

[48] Tekalign M. Soil, plant, water, fertilizer, animal manure and compost analysis. Working Document No 13. International Livestock Research Center for Africa (ILCA). Addis Ababa, Ethiopia. 1991.

[49] Vander, Z. and Beukema H. Introduction to potato production. Center for Agricultural Publishing and Documentation (Pudoc), Wageningen. 1990. 92-96 pp.

[50] Murtada Y. Effect of Seed Rate and Nitrogen on Growth and Yield of Tef Grass (Eragrostis tef (Zucc.) Trotter). MSc thesis, University of Khartoum. Khartoum, Sudan. 2004.

[51] Asmare M., Markku Y. and Birru Y. Effects of lime, wood Ash, manure and mineral $P$ fertilizer rates on acidity related chemical properties and growth and $\mathrm{P}$ uptake of wheat (Triticum aestivum L.) on acid soil of Farta district, northwestern highlands of Ethiopia. International Journal of Agriculture and Crop Sciences, SSN 2227-670X. SSN 2227-670X. 2015. Vol 8 (2) 256-269 pp.

[52] Adera S. Response of tef (Eragrostis te f(Zucc.) Trotter] to different blended fertilizer rates on Vertisols in Jama district, northeastern Ethiopia. An MSc thesis, Haramaya University, Haramaya, Ethiopia. 2016.

[53] Gasim, S. Effect of nitrogen, phosphorus and peed rate on growth, yield and quality of forage maize (Zea mays). MSc Thesis, Faculty of Agriculture, University of Khartoum. Khartoum, Sudan. 2001.

[54] Anteneh A., Birru Y., Yihenew G. and Tadele A.. 2014. The Role of Biochar on Acid Soil Reclamation and Yield of Tef (Eragrostis tef [Zucc] Trotter) in Northwestern Ethiopia. Published by Canadian Center of Science and Education. ISSN 1916-9752 E-ISSN 1916-9760. Journal of Agricultural Science; Vol. 6, No. 1.

[55] Friesen D., Juo A., Miller M. Liming and lime-phosphoruszinc interactions in two Nigerian Ultisols. I. Interaction in the Soil. Soil Science Society of America Journal. 1980. 44: 1221-1226.

[56] Vance E. and Mitchell C. Beneficial use of wood ash as an agricultural soil amendment: case studies from the United States forest products industry. In: Power JF, Dick WA (eds) Land application of agricultural, industrial and municipal by-products. SSSA, Madison. 2000. 567-582.

[57] Workneh B. Growth, lodging and yield of tef (Eragrostis tef) as influenced by seed size and depth of sowing. MSc Thesis, Haramaya University, Haramaya, Ethiopia. 2009. 